\title{
Carbohydrate-Binding Specificity of the Daffodil (Narcissus pseudonarcissus) and Amaryllis (Hippeastrum hybr.) Bulb Lectins'
}

\author{
Hanae Kaku, Els J. M. Van Damme, ${ }^{*}$ Willy J. Peumans, ${ }^{*}$ and Irwin J. Goldstein ${ }^{2}$ \\ Department of Biological Chemistry, University of Michigan, Ann Arbor, Michigan 48109 and ${ }^{*}$ Laboratorium voor \\ Plantenbiochemie, Katholieke Universiteit Leuven, Willem de Croylaan 42, B-3030 Leuven (Heverlee), Belgium
}

The carbohydrate binding specificity of the daffodil (Narcissus pseudonarcissus; NPA) and amaryllis (Hippeastrum hybr.; HHA) lectins, isolated from extracts of their bulbs by affinity chromatography on immobilized mannose, was studied by quantitative precipitation, sugar hapten inhibition, and affinity chromatography on the immobilized lectins. These lectins gave strong precipitation reactions with several yeast mannans, but did not precipitate with $\alpha$-D-glucans (e.g., dextrans and glycogen). Interestingly, both lectins reacted strongly with yeast galactomannans having multiple nonreducing terminal $\alpha$-D-galactosyl groups, a synthetic linear $\alpha-1,6$-mannan, and an $\alpha-1,3$-mannan ( $D P=30$ ). Treatment of the linear $\alpha-1,3$-mannan with periodate, resulting in oxidation of the terminal, nonreducing mannosyl group, did not reduce its reactivity with NPA or HHA. Taken together, these observations suggest that NPA and $H H A$ react not only with terminal but also with internal $\alpha$-D-mannosyl residues. Sugar hapten inhibition studies showed these lectins to possess the greatest specific activity for $\alpha$-D-mannosyl units whereas D-Gle and D-GlcNAc did not inhibit either lectin precipitation system. Of the oligosaccharides tested, the best inhibitor of NPA interaction was $\alpha-1,6$-linked mannotriose, which was twice as good an inhibitor as $\operatorname{Man} \alpha 1,6 \mathrm{Man} \alpha-O-\mathrm{Me}$ and 10 times better than methyl $\alpha-\mathrm{D}$-mannoside. On the other hand, oligosaccharides containing either 1,3- or 1,6-linked mannosyl units were good inhibitors of the HHA-mannan precipitation system (6-to 20-fold more active than D-Man). These results indicate that both lectins appear to possess an extended binding site(s) complementary to at least three 1,6 -linked $\alpha$-mannosyl

\footnotetext{
${ }^{1}$ This research was supported by NIH Grant GM 29470 and grants from the National Fund for Scientific Research (Belgium) (W.J.P. is Senior Research Associate and E.J.M.V.D. Research Assistant of this fund).

${ }^{2}$ To whom correspondence should be addressed.
}

units. Various glycosylasparagine glycopeptides which contain $\alpha-1,6-$ Man units were retarded on the immobilized NPA column. On the other hand, those containing either $\alpha-1,3$ - or $\alpha-1,6$-mannosyl residues were retarded on the immobilized HHA column; Man $_{5}-$ GleNAc $_{2}-A s n$ [containing two $\operatorname{Man} \alpha 1,3(\operatorname{Man} \alpha 1,6)$ units] bound to the HHA column. On the contrary, glycopeptides with hybrid type glycan chains were not retarded on either column. These two new lectins which differ in their fine sugar binding specificity from each other, and also from the snowdrop lectin, should prove to be useful probes for the detection and preliminary characterization of glycoconjugates on cell surfaces and in solution. 1990 Academic Press, Inc.

A number of mannose/glucose-binding lectins have been isolated and studied (1). Of these, concanavalin $A$ (Con $\mathrm{A})^{3}$ from the jack bean (Canavalia ensiformis) is the most widely known and intensively investigated plant lectin, and its utility as a tool in biochemistry, cell biology, immunology, and hematology is well established (24). The sugar binding specificity of Con A was shown to involve the pyranose forms of $\mathrm{D}$-glucose and $\mathrm{D}$-mannose, which contain similar hydroxyl group configurations at the 3-, 4-, and 6-positions (5).

Recently we reported on the sugar binding specificity of a new mannose-binding lectin isolated from snowdrop (Galanthus nivalis; GNA) bulbs, which can distinguish $\mathrm{D}$-mannose from $\mathrm{D}$-glucose because of its high specificity for the $\mathrm{C}-2$ axial hydroxyl group of $D$-mannose (6). This unique sugar binding specificity may make GNA a useful

\footnotetext{
${ }^{3}$ Abbreviation used: Con A, concanavalin $\Lambda$; GNA, Galanthus nivalis lectin; NPA, Narcissus pseudonarcissus lectin; HHA, Hippeastrum hybr. lectin; PBS, $10 \mathrm{mM}$ phosphate buffer ( $\mathrm{pH} 7.2$ ) containing $0.1 \mathrm{mM} \mathrm{CaCl}_{2}, 0.04 \% \mathrm{NaN}_{3}$, and $150 \mathrm{mM} \mathrm{NaCl}$.
}

$0003-9861 / 90 \$ 3.00$ Copyright (C) 1990 by Academic Press, Inc. 
tool in biomedical research. In fact, murine IgM and human $\alpha_{2}$-macroglobulin were readily purified from the corresponding sera of these species using affinity chromatography on immobilized snowdrop bulb lectin (7).

We report herein the detailed carbohydrate binding properties of two further D-mannose-specific lectins isolated from daffodil (Narcissus pseudonarcissus; NPA) and amaryllis (Hippeastrum hybr.; HHA) bulbs, both of which are also members of the same family to which the snowdrop lectin belongs. The sugar-binding specificity of these three lectins is also compared.

\section{MATERIAL AND METHODS}

The daffodil and amaryllis lectins were isolated from extracts of their bulbs by affinity chromatography on an immobilized mannose column as previously reported (8).

Saccharides and glycoproteins. Various monosaccharides and their derivatives were commercially available. D-Altrose and 6-deoxy-Dmannose were the gifts of Dr. N K. Richtmyer of the National Institutes of Health.

Man $\alpha 1,3 \mathrm{Man}$, and Man $\alpha 1,3 \mathrm{Man}-\alpha-O-\mathrm{Me}$ were the gifts of $\mathrm{Dr}$. K. L. Matta of Roswell Park Memorial Institute, Buffalo, NY, $\operatorname{Man} \alpha 1,4 \mathrm{Man}-\alpha-O-\mathrm{Me}$ and $\operatorname{Man} \alpha 1,6 \mathrm{Man}-\alpha-O-\mathrm{Me}$ were purchased from the Sigma Chemical Co. (St. Louis, MO). Man $\alpha 1,6 \mathrm{Man} \alpha 1,6 \mathrm{Man}$ and $\operatorname{Man} \alpha 1,2 \operatorname{Man} \alpha 1,2 \mathrm{Man}$ were the gifts of Dr. C. E. Ballou of the University of California, Berkeley. Man $\alpha 1,6(\operatorname{Man} \alpha 1,3)$ Man- $\alpha-O-\mathrm{Me}$ was the gift of Dr. J. P. Carver of the University of Toronto.

Asparagine-glycopeptides (GP-IIIA, GP-IIIB, GP-IIIC, GP-IV, GP-V) were the gifts of Dr. H. Nomoto and Dr. Y. Inoue of Tokyo University, Japan, and their labeled products were prepared as previously reported by Dr. N. Shibuya (6).

Yeast galactomannans and mannans from various strains were supplied by Dr. P. A. J. Gorin of Universidade Federal Do Panana, Brazil. A synthetic linear $\alpha$-1,6-D-mannan, an $\alpha$-1,3-D-mannan (degree of polymerization $=30$ ) and an $\alpha-1,3-D$-glucan were generously provided by Dr. C. Schuerch, State University of New York at Syracuse (9-11). Elsinan, elsinotriose (Glc $\alpha 1,3 \mathrm{Glc} \alpha 1,4 \mathrm{Glc}$ ) and elsinotetraose (Glc $\alpha 1,3 \mathrm{Glc} \alpha 1,4 \mathrm{Glc} \alpha 1,4 \mathrm{Glc}$ ) were the gifts of Dr. A. Misaki of Osaka City University, Japan. Pullulan, glycogen (oyster), dextran B-1355$S$ and dextran B-1308-S were available from previous studies.

Periodate oxidation of a linear $\alpha 1,3-1-m a n n a n$. A linear $\alpha-1,3-\mathrm{D}$ mannan (DP $=30 ; 3 \mathrm{mg}$ ) dissolved in $80 \mu \mathrm{l}$ of $0.05 \mathrm{M} \mathrm{NaOH}$ was neutralized with $0.05 \mathrm{M} \mathrm{HCl}$ followed by incubation with $\mathrm{NaIO}_{4}$ solution (final concentration was $50 \mathrm{mM}$ ) in the dark at $4^{\circ} \mathrm{C}$ for $72 \mathrm{~h}$. Following destruction of excess periodate by the addition of ethyleneglycol, the oxidized product was reduced overnight with sodium borohydride 0.5 $\mathrm{mg}$ ) at $4^{\circ} \mathrm{C}$ and $\mathrm{pH} 7.0$, followed by dialysis against distilled water (six times using spectrapor MWCO:1000) and lyophilization.

Oxidation of the mannan was confirmed by determination of glycerol using a glycerol analysis kit (Boehringer-Mannheim Biochem) following treatment of the oxidized, $\mathrm{NaBH}_{4}$-reduced mannan with 0.2 $\mathrm{M} \mathrm{H}_{2} \mathrm{SO}_{4}$ at room temperature for $15 \mathrm{~h}$. The total sugar content was determined by the phenol-sulfuric acid method (12).

Quantitative precipitation and precipitation inhibition assay. Quantitative precipitation assays were carried out by a microprecipitation technique. NPA (20 to $23 \mu \mathrm{g}$ ) or HHA (20 to $22 \mu \mathrm{g})$ was added to varying amounts of glycoproteins or polysaccharides in a total volume of $150 \mu \mathrm{l}$. After incubation at $37^{\circ} \mathrm{C}$ for $1 \mathrm{~h}$, the mixtures were kept at $4^{\circ} \mathrm{C}$ for 2 days and centrifuged $(11,500 \mathrm{rpm}, 10 \mathrm{~min})$; protein in the precipitates was determinated by Lowry's method (13) using bovine serum albumin as standard.

Sugar inhibition of the precipitation reactions was carried out by adding increasing amounts of sugar or sugar derivative to precipitation

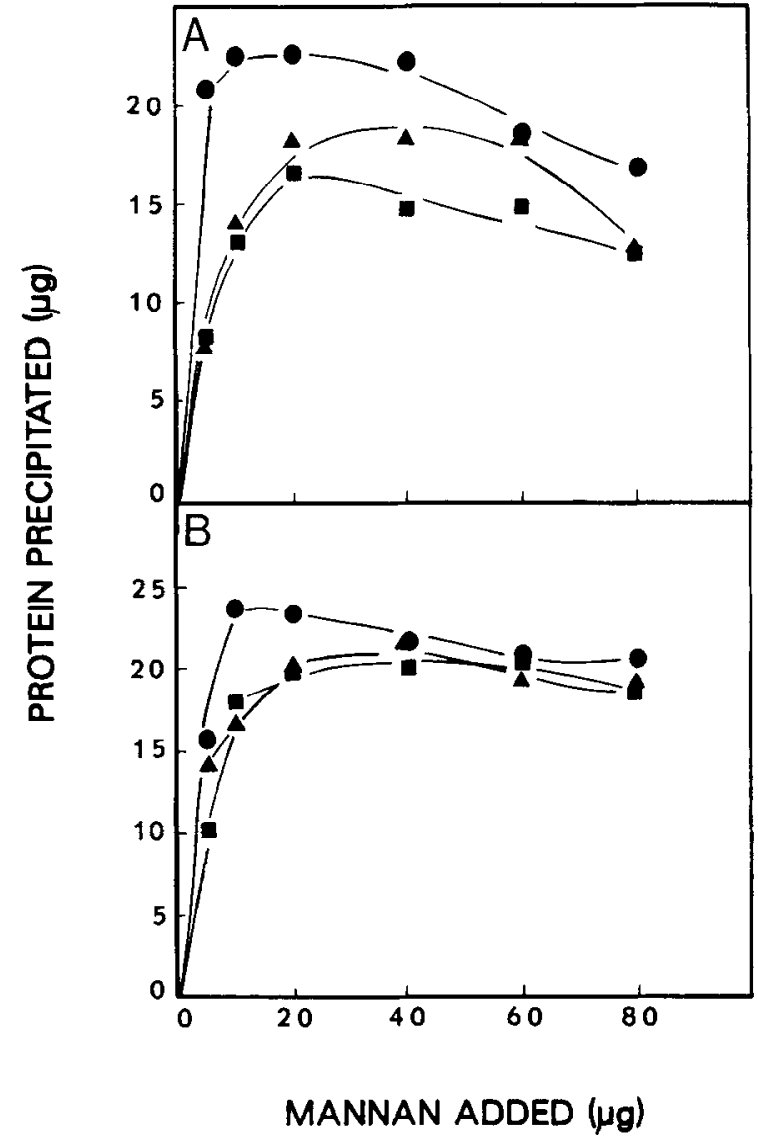

FIG. 1. Quantitative precipitation of yeast mannans by NPA (A) and HHA (B). The protein concentrations were 23 and $22 \mu \mathrm{g}$ of NPA and HHA, respectively. $\bullet, S$. cerevisiae; $\boldsymbol{\Delta}, P$. pastoris;,$H$. capsulata.

systems containing lectin and Pichia pastoris mannan. The precipitated protein was determined by the procedure of Lowry.

Immobilization of lectins and affinity chromatography. The affinity matrices of NPA and HHA, prepared by coupling these lectins to CNBr-activated Sepharose 4B (Pharmacia, Sweden), were determined to contain ca. $2 \mathrm{mg}$ of lectin per milliliter of each gel.

Labeled asparagine glycopeptides were applied to the NPA- or HHA Sepharose columns $(0.6 \times 15 \mathrm{~cm})$, followed by elution with PBS and PBS containing 0.5 M methyl $\alpha$-D-mannoside (Me- $\alpha$-D-Man).

\section{RESULTS}

Precipitation assay. The precipitin curves of NPA and HHA with various yeast mannans and galactomannans are shown in Figs. 1 and 2. Saccharomyces cerevisiae and $P$. pastoris mannans (14) which contain multiple D-mannosyl side chains attached to the $\alpha 1,6$-linked mannose backbone gave pronounced precipitation with NPA and HHA. Hansenula capsulata mannan (15), which is a linear mannan, also reacted with both lectins (Figs. 1A and B).

Interestingly, galactomannans isolated from several different strains of yeast, e.g. Candida lipolytica, Torulopsis-lactis condensi and Torulopsis gropengiesseri, and 


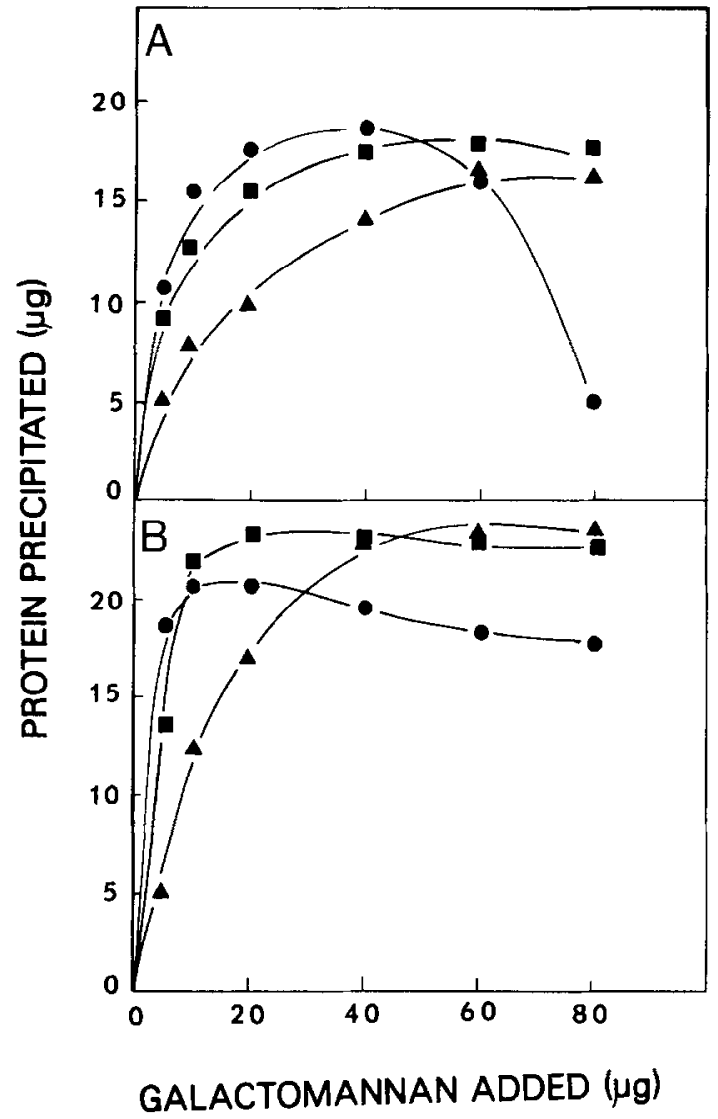

FIG. 2. Quantitative precipitation of yeast galactomannans by NPA (A) and HHA (B). The protein concentrations were 23 and 22 $\mu \mathrm{g}$ of NPA and HHA, respectively. $\bullet, C$. lipolytica; $\mathbf{\bullet}, T$. gropengiesseri; A, T. lactis-condensi.

which are substituted to different extents with side chains consisting of $\alpha$-D-galactosylmannosyl or mannobiosyl units on their $\alpha 1,6$-mannose backbone (16), also reacted strongly with NPA and HHA (Figs. 2A and 2B). In addition, a synthetic linear $\alpha 1,6-$ and an $\alpha 1,3-\mathrm{D}$ mannan ( $D P=30$ ) were also precipitated by NPA and HHA (Fig. 3). Furthermore, the periodate-oxidized $\alpha 1,3-$ D-mannan, which contains a modified nonreducing terminal residue, still retained activity for these lectins similar to the untreated $\alpha 1,3-\mathrm{D}$-mannan. These results suggested that NPA and HHA may have greater affinity for internal mannosyl residues than for nonreducing terminal units.

Elsinan, a fungal glucan having repeating units of $-3 \mathrm{Glc} \alpha 1,4 \mathrm{Glc} \alpha 1,4 \mathrm{Glc} \alpha 1-$ (17), gave a small amount of precipitate with both mannose-specific lectins, but pullulan, which contains -6Glc $\alpha 1,4 \mathrm{Glc} \alpha 1,4 \mathrm{Glc} \alpha 1$ - sequences, glycogen, and synthetic linear $\alpha 1,3$-glucan (11) did not react with these lectins (data not shown). Moreover, dextran B-1355-S having ca. $50 \% \alpha 1,6$-linked glucose and $35 \% \alpha 1,3$-linked glucose, and dextran B-1308-S (93\% $\alpha 1,6$-linked glucose) (18) also failed to precipitate with NPA and HHA.
Inhibition of precipition reaction by haptenic sugars. The results of carbohydrate binding specificity studies of NPA and HHA, as conducted by sugar hapten inhibition of precipitation with the $P$. pastoris mannan, are presented in Tables I and II. It has already been reported that these lectins have specific binding activity toward D mannose. D - Glucose (C-2 epimer of mannose), its $\alpha$-and $\beta$-methyl glucosides, and D-talose (C-4 epimer) did not inhibit the lectin-mannan precipitation system at $100 \mathrm{mM}$, nor did D-altrose (C-3 epimer) at $50 \mathrm{mM}$. Furthermore, 3-deoxy-D-Man, 6-deoxy-D-Man and D-lyxose were all poorer inhibitors than D-mannose. Interestingly, modifications at the $\mathrm{C}-2$ position of mannose (2deoxy-2-fluoro-D-Man, $p$-nitrophenyl 2- $O$-methyl- $\alpha$-DMan, 2-deoxy-D-Man, and $N$-acetyl mannosamine) resulted in compounds that were also poor inhibitors. These results strongly suggest that the $\mathrm{C}-2$ axial and the C-3, C-4, and C-6 equatorial hydroxyl groups of mannose are all required for binding to these lectins, with the $\mathrm{C}-2$ axial hydroxyl group being especially critical.

The $\alpha$-anomers of methyl and $p$-nitrophenyl mannosides were 2 to 5 times better inhibitors than their $\beta$-anomeric derivatives. Moreover, comparison of methyl $\alpha$ and $\beta$-D-mannoside with those of their $p$-nitrophenyl derivatives, indicate that the hydrophobic $p$-nitrophenyl group does not have an appreciable influence on the binding of these sugar glycosides to these lectins.

Of the oligosaccharides tested, $\alpha 1,6$-linked mannotriose was the best inhibitor of the NPA interaction, being

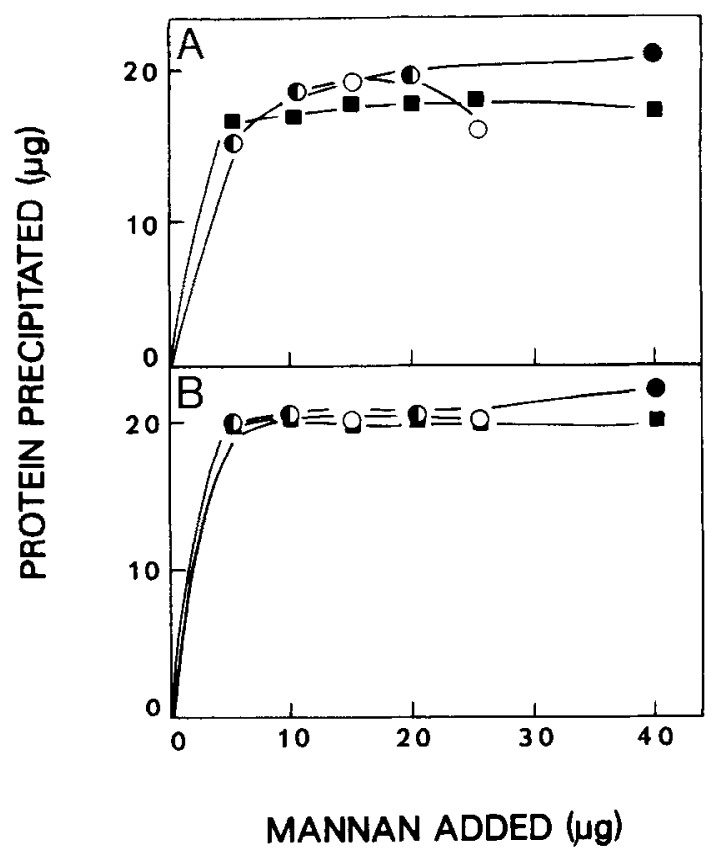

FIG. 3. Quantitative precipitation of synthetic linear mannans by NPA (A) and HHA (B). The protein concentration was $20 \mu \mathrm{g}$ each for NPA and HHA. $₫, \alpha$-1,6-D-mannan; $\bullet \alpha-1,3-\mathrm{D}-$ mannan; $O, \alpha-1,3-\mathrm{D}-$ mannan modified by periodate oxidation. 
TABLE I

Inhibition by Monosaccharides of $P$. pastoris Mannan Precipitation by NPA and HHA ${ }^{a}$

\begin{tabular}{lcc}
\hline & \multicolumn{2}{c}{$\begin{array}{c}\text { mM Required for } 50 \% \\
\text { inhibition }\end{array}$} \\
\cline { 2 - 3 } \multicolumn{1}{c}{ Sugar } & NPA & HHA \\
\hline D-Man & 7.2 & 20.0 \\
Me- $\alpha$-D-Man & 6.0 & 13.0 \\
Me- $\beta$-D-Man & 13.0 & 37.0 \\
$p-\mathrm{NO}_{2}$ Ph- $\alpha$-D-Man & 3.7 & 6.9 \\
$p$-NO 2 Ph- $\beta$-D-Man & 17.0 & $20.0(38)^{b}$ \\
Man 1-phosphate & 12.4 & $30.0(0)$ \\
Man 6-phosphate & $15.0(0)$ & $30.0(0)$ \\
2-Deoxy-2-fluoro-D-Man & $50.0(16)$ & $15.0(0)$ \\
$p$-NO 2 Ph-2-O-Me- $\alpha$-D-Man & $15.0(32)$ & $100.0(0)$ \\
2-Deoxy-D-Man & $100.0(0)$ & $80.0(11)$ \\
3-Deoxy-D-Man & $50.0(24)$ & $100.0(0)$ \\
6-Deoxy-D-Man & $50.0(63)$ & $100.0(9)$ \\
D-I yxose & $100.0(15)$ & \\
\hline
\end{tabular}

${ }^{a}$ These systems were not inhibited by D-Glc, D-Gal, L-Gal, D-talose, Me- $\alpha$-D-Glc, Me- $\beta$-D-Glc, L-Glc, D-Ara, D-Fuc, L-Fuc, GlcNAc, and ManNAc at $100 \mathrm{mM}$, and D-altrose at $50 \mathrm{~mm}$.

${ }^{b}$ The numbers in parentheses indicate the percentage inhibition given by the concentration of saccharide noted.

twice as good an inhibitor as Man $\alpha 1,6 \mathrm{Man}-\alpha-O-\mathrm{Me}$, and 10 times better than methyl $\alpha$-D-mannoside. Moreover, methyl $\alpha 1,6$-linked mannobioside was 7 -fold more active than Man $\alpha 1,6 \mathrm{Glc}$. Alpha-1,2-mannobiose and $\alpha 1,3$ mannobiose and its $\alpha$-methyl glycoside were also good inhibitors of the NPA interaction; however, Man $\alpha 1$, $4 \mathrm{Man}-\alpha-O$-Me showed reduced inhibitory activity, suggesting that the $\mathrm{C}-4$ hydroxyl group of the penultimate mannose may be of importance for interaction. This observation was also supported by the poor inhibitory activity of $\operatorname{Man} \alpha 1,2(\operatorname{Man} \alpha 1,4)$ Man- $\alpha-O-M e$. Alpha-1,2linked mannotriose (Man $\alpha 1,2 \mathrm{Man} \alpha 1,2 \mathrm{Man}$ ) also had reduced inhibitory activity compared to the corresponding disaccharide Man $\alpha 1,2$ Man. The branched mannotrioside, Man $\alpha 1,3(\operatorname{Man} \alpha 1,6)$ Man- $\alpha-O-M e$, was less active than the disaccharide Man $\alpha 1,6 \mathrm{Man}-\alpha-O$-Me for the NPA-mannan precipitation system.

Alpha-1,6-linked mannose oligosaccharides were among the best inhibitors of the HHA interaction being 8 to 20 times more active than D-mannose. $\operatorname{Man} \alpha 1,6 \operatorname{Man} \alpha 1,6 \operatorname{Man}$ was twice as $\operatorname{good}$ as $\operatorname{Man} \alpha 1$, $6 \mathrm{Man}-\alpha-O-\mathrm{Me}$ and 13 times more potent than Me- $\alpha$-Dmannoside. Man $\alpha 1,3 \mathrm{Man}-\alpha-O-\mathrm{Me}$ was also a good inhibitor, being 2 times more active than Man $\alpha 1$,3Man and 7 times better than Me- $\alpha$-D-mannoside for the HHA interaction. The branched mannotriose, Man $\alpha 1,3-$ $(\operatorname{Man} \alpha 1,6) \mathrm{Man}-\alpha-\mathrm{O}-\mathrm{Me}$, was also a good inhibitor, which was twice as good as the disaccharides Man $\alpha 1,3$ Man- $\alpha-O-$ Me and Man $\alpha 1,6 \mathrm{Man}-\alpha-O-\mathrm{Me}$.
On the contrary, $\beta$-linked mannobioses; e.g., $\operatorname{Man} \beta 1$, $2 \mathrm{Man}$ and $\operatorname{Man} \beta 1,4 \mathrm{Man}$, were very poor inhibitors for both lectin precipitation systems. Maltose and nigerose gave no inhibition at concentrations of 100 and $50 \mathrm{mM}$, respectively, whereas elsinotetraose (Glc $\alpha 1,3 \mathrm{Glc} \alpha 1$, $4 \mathrm{Glc} \alpha 1,4 \mathrm{Glc}$ ) had a detectable effect on both lectin systems (see Table II).

These results demonstrated that NPA appears to exhibit a preference for $\alpha 1,6$-linked mannosyl units, whereas HHA shows high binding specificity for both $\alpha 1,3-$ and $\alpha 1,6$-linked mannosyl units but with a preference for the $\alpha 1,6$-linkage.

Affinity chromatography. Various glycosylasparagine-glycopeptides isolated from ovalbumin and labeled with ${ }^{3} \mathrm{H}$ by reductive methylation exhibited differential behavior upon affinity chromatography on immobilized NPA (Fig. 4A). GP-V and GP-IV, which contain $\alpha 1$,6-Man units (Table III), were greatly retarded on this column, whereas GP-IIIB and $\mathrm{Man}_{9} \mathrm{GlcNAc}_{2}$-Asn showed only slight retardation on NPA-Sepharose. Glycopeptides with hybrid type glycan chains containing a bisecting GlcNAc residue, e.g., GP-IIIA and GP-IIIC, were not retarded.

Interestingly, GP-V, which possesses two $\operatorname{Man} \alpha 1,3-$ (Man $\alpha 1,6)$ units (Table III), bound completely to HHASepharose (Fig. 4B). GP-IV and GP-IIIB showed pronounced retardation; however, $\mathrm{Man}_{9} \mathrm{GlcNAc}_{2}$-Asn was only slightly retarded on the HHA-Sepharose, and GP.

TABLE II

Inhibition by Oligosaccharides of $P$. pastoris Mannan Precipitation by NPA and HHA

\begin{tabular}{|c|c|c|}
\hline \multirow[b]{2}{*}{ Sugar } & \multicolumn{2}{|c|}{$\begin{array}{c}\text { mM Required for } 50 \% \\
\text { inhibition }\end{array}$} \\
\hline & NPA & HHA \\
\hline $\operatorname{Man}(\alpha 1,2) \operatorname{Man}$ & 2.2 & 6.3 \\
\hline $\operatorname{Man}(\alpha 1,3) \operatorname{Man}$ & 2.6 & 3.4 \\
\hline $\operatorname{Man}(\alpha 1,3) \operatorname{Man}-\alpha-O-\mathrm{Me}$ & 2.3 & 1.9 \\
\hline $\operatorname{Man}(\alpha 1,6) \operatorname{Man}-\alpha-O-\mathrm{Me}$ & 1.4 & 2.4 \\
\hline $\operatorname{Man}(\alpha 1,4)$ Man- $\alpha-O-\mathrm{Me}$ & $10.0(45)^{a}$ & $10.0(42)$ \\
\hline $\operatorname{Man}(\alpha 1,6)$ Gilc & 10.0 & $10.0(19)$ \\
\hline $\operatorname{Man}(\alpha 1,2) \operatorname{Man}(\alpha 1,2) \operatorname{Man}$ & 4.3 & 5.6 \\
\hline $\operatorname{Man}(\alpha 1,6) \operatorname{Man}(\alpha 1,6) \operatorname{Man}$ & 0.58 & 1.0 \\
\hline $\operatorname{Man}(\beta 1,2) \operatorname{Man}$ & $20.0(7)$ & $7.5(0)$ \\
\hline $\operatorname{Man}(\beta 1,4) \operatorname{Man}$ & $20.0(26)$ & $7.5(0)$ \\
\hline Gic $(\alpha 1,4)$ Glc & $100.0(0)$ & $100.0(0)$ \\
\hline Glc $(\alpha 1,3)$ Glc & $50.0(0)$ & $50.0(0)$ \\
\hline $\operatorname{Glc}(\alpha 1,3) \operatorname{Glc}(\alpha 1,4) \operatorname{Glc}$ & $30.0(0)$ & $30.0(15)$ \\
\hline $\operatorname{Glc}(\alpha 1,3) \operatorname{Glc}(\alpha 1,4) \operatorname{Glc}(\alpha 1,4)$ Gle & $20.0(22)$ & $20.0(14)$ \\
\hline $\begin{array}{l}\operatorname{Man}(\alpha 1,6) \\
\operatorname{Man}(\alpha 1,3)\end{array}>\operatorname{Man}-\alpha-O-\mathrm{Me}$ & 1.9 & 1.5 \\
\hline $\begin{array}{l}\operatorname{Man}(\alpha 1,4) \\
\operatorname{Man}(\alpha 1,2)\end{array}=\operatorname{Man} \alpha O \mathrm{Me}$ & $2.0(8)$ & \\
\hline
\end{tabular}

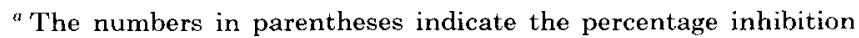
given by the concentration of saccharide noted.
} 


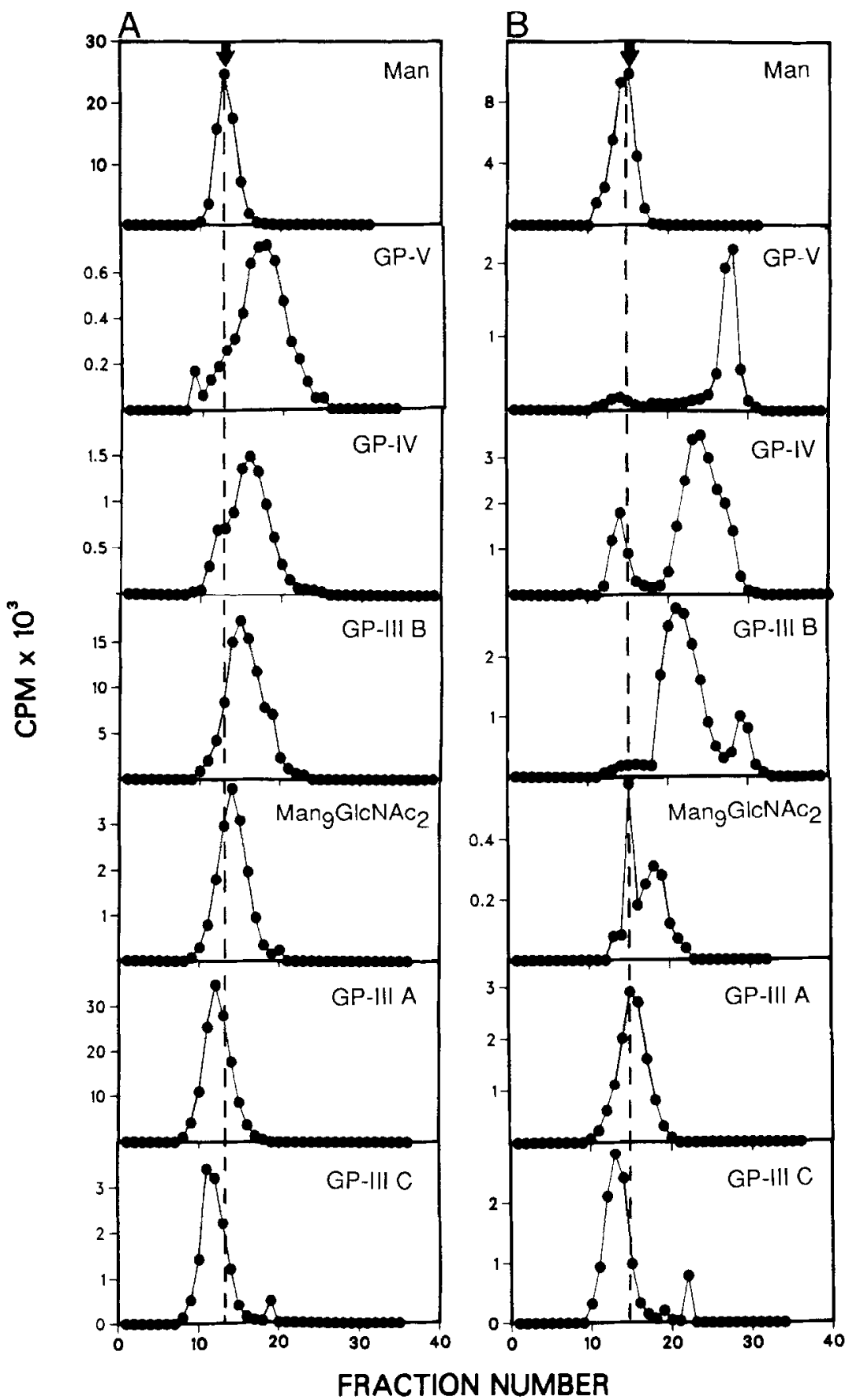

FIG. 4. Elution profiles of glucosylasparagines on NPA- (A) and HHA-Sepharose (B). $\left[{ }^{3} \mathrm{H}\right]$-labeled mannose and glucosylasparagine glycopeptides were applied on their lectin-Sepharose columns $(0.6 \times 15 \mathrm{~cm})$, followed by elution with PBS and PBS containing $0.5 \mathrm{M}$ Me- $\alpha$-D-Man. The arrow indicates the addition of $0.5 \mathrm{M} \mathrm{Me}-\alpha$-D-Man in the eluent and the dashed line indicates the elution position of $\mathrm{D}-\mathrm{Man}$.

IIIA and GP-IIIC were not retarded, similar to the results obtained for NPA-Sepharose.

\section{DISCUSSION}

Recently we described the detailed carbohydrate binding specificity of the snowdrop lectin (GNA, (6)). In the present paper we have examined the carbohydrate binding specificity of the lectins isolated from bulbs of the daffodil and amaryllis, two additional members of the family Amaryllidaceae. All three of these lectins are highly specific for D-mannose. Both the daffodil lectin (NPA) and amaryllis lectin (HHA) reacted strongly with several yeast mannans, galactomannans, a synthetic lin- 
TABLE III

Structures of Glycosylasparagine Glycopeptides

\begin{tabular}{|c|c|}
\hline Oligosaccharide & Structure \\
\hline$G P-V$ & $\begin{array}{l}\operatorname{Man}(\alpha 1,6) \\
\operatorname{Man}(\alpha 1,3)\end{array} \frac{\operatorname{Man}(\alpha 1,6)}{\operatorname{Man}(\alpha 1,3)}>\operatorname{Man}(\beta 1,4) \mathrm{R}$ \\
\hline GP-IV & $\begin{array}{l}\operatorname{Man}(\alpha 1,6) \\
\operatorname{Man}(\alpha 1,3)>\operatorname{Man}(\alpha 1,6) \\
\quad \operatorname{Man}(\alpha 1,2) \operatorname{Man}(\alpha 1,3)\end{array}$ \\
\hline GP-IIIB & $\begin{aligned} \operatorname{Man}(\alpha 1,2) & \operatorname{Man}(\alpha 1,6) \\
\operatorname{Man}(\alpha 1,3) & >\operatorname{Man}(\alpha 1,6)>\operatorname{Man}(\beta 1,4) \mathrm{R} \\
& \operatorname{Man}(\alpha 1,2) \operatorname{Man}(\alpha 1,3)\end{aligned}$ \\
\hline MangGlcNAc & $\begin{array}{l}\operatorname{Man}(\alpha 1,2) \operatorname{Man}(\alpha 1,6) \\
\operatorname{Man}(\alpha 1,2) \operatorname{Man}(\alpha 1,3)\end{array} \quad=\operatorname{Man}(\alpha 1,6)>\operatorname{Man}(\beta 1,4) \mathrm{R}$ \\
\hline CP-IIIA & 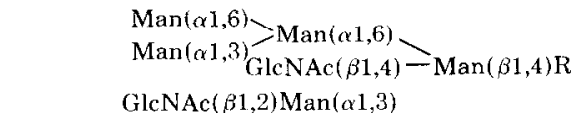 \\
\hline GP-IIIC & $\begin{array}{r}\operatorname{Man}(\alpha 1,3) \operatorname{Man}(\alpha 1,6) \\
\operatorname{GlcNAc}(\beta 1,4)\end{array}-\operatorname{Man}(\beta 1,4) \mathrm{R}$ \\
\hline
\end{tabular}

Note. $\mathrm{R}=\operatorname{GlcNAc}(\beta 1,4) \operatorname{GlcNAc}(\beta 1, N) \operatorname{Asn}$.

ear $\alpha 1,6$-linked mannan and an $\alpha 1,3$-linked mannan, suggesting that these lectins recognize both terminal and internal $\alpha$-D-mannosyl residues (Figs. 1, 2, and 3). Furthermure, a synthelic linear $\alpha 1,3$-linked mannan modified by treatment with periodate still retained high activity similar to that of the untreated mannan. These observations indicate that both lectins recognize internal mannosyl residues; the results also demonstrate that NPA and HHA have somewhat different sugar binding specificites from the snowdrop lectin, which also reacts strongly with various yeast mannans, but only slightly with galactomannans and the linear $\alpha 1,3$-linked mannan from Trichosporon cutaneum (6).

The results of precipitation studies also showed that of the $\alpha$-glucans examined, only elsinan, a fungal $\alpha$-Dglucan composed of repeating units of -3Glc $\alpha 1$, 4Glc $\alpha 1,4 \mathrm{Glc} \alpha 1-$ (17), gave an appreciable amount of precipitate with NPA and HHA; a similar result was also obtained with GNA (6). Of the glucooligosaccharides tested as inhibitors, only elsinotetraose (GIc $\alpha 1$, $3 \mathrm{Glc} \alpha 1,4 \mathrm{Glc} \alpha 1,4 \mathrm{Glc})$ showed appreciable inhibition of lectin precipitation, whereas maltose and nigerose did not inhibit at the concentrations tested (Table II). These results suggest that a portion of the three dimensional structure of elsinan such as elsinotriose, elsinotetraose, and/or longer elsinosaccharides may fit the binding site of these lectins.

Thus, all three of these lectins derived from the bulbs of monocotyledonous plants can readily distinguish Dmannose from D-glucose (D-glucose and its $\alpha$ - and $\beta$-glycosides were very poor inhibitors of these lectins, even at $100 \mathrm{~mm}$ concentration). These results also indicate that the sugar binding specificity of these lectins is quite different from the previously described mannose/glucose binding lectins, e.g., Con A (5), lentil $(19,20)$, pea (21), fava bean $(20,22,23)$, and the Bowringia milbraedii lectin (24). For example, 2-deoxy-D-mannose and $p$-nitrophenyl 2- $O$-methyl- $\alpha$-D-mannoside were good inhibitors of Con A-polysaccharide interaction (25). However, these derivatives modified at the $\mathrm{C}-2$ position of mannose were poorer inhibitors than D-mannose for NPA, HHA, and GNA (6) (Table I), indicating that the C-2 axial hydroxyl group of mannose plays a more important role for interaction with these lectins than for Con A.

Comparison of the sugar binding specificities of the three D-mannose-binding lectins on the basis of sugar hapten inhibition of mannan precipitation shows that Man $\alpha 1,3 \mathrm{Man}$ and its methyl $\alpha$-glycoside are 12-14 times better inhibitors than D-mannose for GNA, but only 3 times more active than D-mannose for NPA (Table IV). Interestingly, methyl $\alpha$-Man $\alpha 1,3 \mathrm{Man}$ is 1.8 times more potent than Man $\alpha 1$,3Man for HHA, and 10.5 times more active than $\mathrm{D}$-mannose. The $\alpha 1,6$-linked mannotriose is by far the best inhibitor of HHA, being 20 times more active than mannose; the mannotriose is 12 times more active than mannose of the NPA precipitation system, and is also 2.4 times more potent than methyl $\alpha$ $\operatorname{Man} \alpha 1,6$ Man for both lectin systems.

The combining site(s) of GNA appears to be most complementary to the $\alpha 1,3$-mannobiose sequence, and the nonreducing terminal mannosyl residue is of special importance for this interaction (6). On the contrary, both NPA and HHA appear to exhibit a preference for

\section{TABLE IV}

Inhibition by Various Sugars of Three Mannose-Specific Lectin-Yeast Mannan Precipitation Systems

\begin{tabular}{|c|c|c|c|}
\hline \multirow[b]{2}{*}{ Sugar } & \multicolumn{3}{|c|}{ Relative inhibitory potency } \\
\hline & $\mathrm{GNA}^{a}$ & NPA & HHA \\
\hline D-Man & 1.0 & 1.0 & 1.0 \\
\hline Me- $\alpha$-D-Man & 1.6 & 1.2 & 1.5 \\
\hline Me- $\beta$-1)-Man & 0.3 & 0.2 & 0.5 \\
\hline$p-\mathrm{NO}_{2} \mathrm{Ph}-\alpha-\mathrm{D}-\mathrm{Man}$ & 2.8 & 2.0 & 2.9 \\
\hline$p-\mathrm{NO}_{2} \mathrm{Ph}-\beta-\mathrm{D}-\mathrm{Man}$ & 1.9 & 0.4 & $<1.0$ \\
\hline $\operatorname{Man}(\alpha 1,2) \operatorname{Man}$ & 2.1 & 3.3 & 3.2 \\
\hline $\operatorname{Man}(\alpha 1,3) \operatorname{Man}$ & 12.1 & 2.8 & 5.9 \\
\hline $\operatorname{Man}(\alpha 1,3) \operatorname{Man}-\alpha-O-M e$ & 14.2 & 3.1 & 10.5 \\
\hline $\operatorname{Man}(\alpha 1,4) \operatorname{Man}-\alpha-O-\mathrm{Me}$ & $1.9^{b}$ & $<0.7$ & $<2.0$ \\
\hline $\operatorname{Man}(\alpha 1,6) \operatorname{Man}-\alpha-O-\operatorname{Me}$ & 4.3 & 5.1 & 8,3 \\
\hline $\operatorname{Man}(\alpha 1,6) \mathrm{Glc}$ & 1.9 & 0.7 & $\ll 2.0$ \\
\hline $\operatorname{Man}(\alpha 1,2) \operatorname{Man}(\alpha 1,2) \operatorname{Man}$ & 3.4 & 1.7 & 3.6 \\
\hline $\operatorname{Man}(\alpha 1,6) \operatorname{Man}(\alpha 1,6) \operatorname{Man}$ & 5.7 & 12.4 & 20.0 \\
\hline $\begin{array}{l}\operatorname{Man}(\alpha 1,6) \\
\operatorname{Man}(\alpha 1,3)>\operatorname{Man}-\alpha-O-M e\end{array}$ & 28.3 & 3.8 & 13.8 \\
\hline
\end{tabular}

${ }^{a}$ These data from Shibuya et al. (6) using the GNA-H. capsulata mannan precipitation system.

${ }^{b} \operatorname{Man}(\alpha 1,4) \operatorname{Man}(S$-benzyl glycoside). 
internal mannosyl units. Furthermore, both of these lectins have an extended binding site for $\alpha 1,6$-mannotriose (two times better than the corresponding disaccharide), although $\alpha 1,3$-linked mannosyl units are also good inhibitors of HHA.

Until recently, only one D-mannose specific plant lectin, isolated from tulip (Tulipa gesneriana) bulbs, was reported (26). This lectin which has properties similar to those of NPA and HHA recognizes $\alpha 1,6$-linked mannooligosaccharide units larger than Man $\alpha 1,6 \mathrm{Man}$. L-Fucose, which bears a structural resemblance to D-mannose (the spatial arrangement of the hydroxyl groups on $\mathrm{C}-2,3$, and 4 of D-mannopyranose is identical to that of the hydroxyl groups at C-4, 3 , and 2 of L-fucose), is also a good inhibitor of the tulip lectin (26), but does not inhibit NPA or HHA. This observation suggests that the sugar binding sites of NPA and HHA are different from that of the tulip lectin. Additionally, this observation also supports the importance of the C-6 hydroxymethyl group of mannose for interactions with NPA and HHA.

The elution behavior of glycosylasparagine glycopeptides and glycoproteins on immobilized NPA and HHA was studied. The glycoproteins carrying high mannose glycan chains, e.g., lima bean lectin (27) and porcine thyroglobulin (28), bind completely to both affinity chromatographic columns, whereas ovalbumin did not bind to either lectin column (data not shown), results very similar to the results using GNA-Sepharose (6). Furthermore, most of the glycosylasparagine glycopeptides such as GP-IIIB, GP-IV, GP-V, and $\mathrm{Man}_{9} \mathrm{GlcNAc}_{2}$-Asn behaved differently on NPA- and HHA-Sepharose (Figs. 4A and 4B); interestingly, only GP-V bound completely to the HHA-Sepharose column.

It is of great interest to observe the behavior on the immobilized NPA- and HHA-Sepharose columns of the series of glycopeptides commencing with $\mathrm{Man}_{9} \mathrm{GlcNAc}_{2}$ Asn and proceeding to GP-IIIB, GP-IV, and GP-V. The $\mathrm{Man}_{9} \mathrm{GlcNAc}_{2}$-Asn glycopeptide containing three Man $\alpha 1,2$ Man disaccharide units is barely retarded on the two columns. GP-IIIB, with two fewer $\alpha 1,2$-linked mannosyl units exposing a Man $\alpha 1,3$ Man unit, is more retarded in both columns, whereas GP-IV, which lacks three $\alpha 1,2$-linked mannosyl units with a more accessible Man $\alpha 1,3 \mathrm{Man}$ disaccharide, is retarded further. Finally, GP-V with two Man $\alpha 1$,3Man units is bound to the HHA column and is the most retarded of the glycopeptides by the NPA column. It is also apparent that the HHASepharose column has the most resolving capacity in that two peaks appear for several of the glycopeptides suggesting impurities in the preparation.
Because of their unique carbohydrate binding specificity, we believe these mannose-binding bulb lectins should be of great utility in investigating the structure of complex carbohydrates.

\section{REFERENCES}

1. Goldstein, I. J., and Poretz, R. D. (1986) in The Lectins (Liener, I. E., Sharon, N., and Goldstein, I. J., Eds.), pp. 51-84, Academic Press, Orlando, FL.

2. Poste, G. (1975) Concanavalin A (Chowdhury, T. K., and Weiss, A. K., Eds.), pp. 117-317, Plenum, New York.

3. Mallucci, L. (1976) in Concanavalin A as a Tool (Bittiger, H., and Schnebli, H. P., Eds.) pp. 69-623, Wiley, London.

4. Lis, H., and Sharon, N. (1986) in The Lectins (Liener, I. E., Sharon, N., and Goldstein, I. J., Eds.), pp. 265-370, Academic Press, Orlando, FL.

5. Goldstein, I. J., Reichert, C. M., and Misaki, A. (1974) Ann. N.Y. Acad. Sci. 234, 284-296.

6. Shibuya, N., Goldstein, I. J., Van Damme, E. J. M., and Peumans, W. J. (1988) J. Biol. Chem. 263, 728-'734.

7. Shibuya, N., Berry, J. E., and Goldstein, I. J. (1988) Arch. Biochem. Biophys. 267, 676-680.

8. Van Damme, E. J. M., Allen, A. K., and Peumans, W. J. (1988) Physiol. Plant. 73, 52-57.

9. Lin, J. W.-P., and Schuerch, C. (1972) J. Polym. 10, 2045-2060.

10. Kong, F., and Schuerch, C. (1984) Macromolecules 17, 983-989.

11. Good, F. J., Jr., and Schuerch, C. (1985) Macromolecules, 18, 595599.

12. Dubois, M., Gilles, K. A., Hamilton, J. K., Rebers, P. A., and Smith, F. (1956) Anal. Chem. 28, 350-356.

13. Lowry, O. H., Rosebrough, N. J., Farr, A. L., and Randall, R. J. (1951) J. Biol. Chem. 193, 265-275.

14. Gorin, P. A. J. (1973) Canad. J. Chem. 51, 2375-2383.

15. Gorin, P. A. J., and Spencer, J. F. T. (1972) Canad. J. Microbiol. 18, 1709-1715.

16. Gorin, P. A. J., Spencer, J. F. T., and Magus, R. J. (1969) Canad. J. Chem. 47, 3569-3576.

17. Tsumuraya, Y., Misaki, A., Takaya, S., and Torii, M. (1978) Carbohydr. Res. 66, 53-65.

18. Seymour, F. R., Slodki, M. E., Plattner, R. D., and Jeanes, A. (1978) Carbohydr. Res. 66, 53-65.

19. Toyoshima, S., Osawa, T, and Tonomura, A. (1970) Biochim. Biophys. Acta. 221, 514-521.

20. Allen, A. K., Desai, N. N., and Neuberger, A. (1976) Biwchem. J. $\mathbf{1 5 5}, 127-135$.

21. Van Wauwe, J.-P., Loontiens, F. G., and De Bruyne, C. K. (1975) Biochim. Biophys. Acta 379, 456-461.

22. Perera, C. B., and Frumin, A. M. (1966) Science 151, 821.

23. Lee, J. K. N., Patchman, E. A., and Frumin, A. M. (19/4) Proc. Natl. Acad. Sci. USA 234, 161-169.

24. Animashaun, T., and Hughes, C. R. (1989) J. Biol. Chem. 264, 4657-4663.

25. Poretz, R. D., and Goldstein, I. J. (1970) Biochemistry 9, 28902896.

26. Oda, Y., and Minami, K. (1986) Eur. J. Biochem. 159, 239-245.

27. Misaki, A., and Goldstein, I. J. (1977) J. Biol. Chem. 262, 69956999.

28. Tsuji, T., Yamamoto, K., Irimura, T., and Osawa, T. (1981) Biochem. J. 195, 691-699. 